\title{
Effect of Soil Tillage on Diversity and Abundance of Macrofungi Associated with Chestnut Tree in the Northeast of Portugal
}

\author{
P. Baptista and A. Martins \\ Escola Superior Agrária de Bragança \\ Apartado 172 \\ 5301-855 Bragança \\ Portugal
}

\author{
T. Lino-Neto and R.M. Tavares \\ Departamento de Biologia/Centro de Biologia \\ Universidade do Minho, Campus de Gualtar \\ 4710-057 Braga \\ Portugal
}

Keywords: Castanea sativa Mill., tillage vs. non-tillage, macrofungi diversity

\begin{abstract}
European chestnut trees (Castanea sativa Mill.) are of great economic importance for wood and fruit production in the northeast of Portugal. In order to maintain the soil free of weeds, farmers traditionally practice several superficial tillages along the year. Phytosanitary problems mainly related with increasing Phytophtora cinnamomi contamination of soils are progressively changing these practices. In this context, the present work intends to evaluate the effect of two different soil management practices (tillage vs. non-tillage) of chestnut orchards on the macrofungi diversity and abundance. During autumn-winter 2003, two neighboring $C$. sativa orchards were selected, one tilled and one non-tilled. In each orchard, five plots of 100 $\mathbf{m}^{2}$ were delimited and weekly all mushrooms, mycorrhizal and non-mycorrhizal, were harvested. The collected sporocarps were identified and quantified in order to evaluate the biodiversity and abundance of species. In this study, 50 macrofungi species belonging to 20 genera were identified. In the tilled orchard 17 species from 12 genera were harvested, mainly from the genera Russula, Macrolepiota, Laccaria, and Inocybe. The non-tilled orchard showed a higher number of species (47) and genera (17), the greater number of species observed belonging to the genera Russula, Inocybe, Cortinarius, Tricholoma, and Laccaria. These results suggest that soil tillage practices decreased significantly the total number of species and the number of mycorrhizal and non-mycorrhizal mushrooms in chestnut orchards.
\end{abstract}

\section{INTRODUCTION}

Chestnut trees as fruit and wood producers have a great economic importance for the rural population in Trás-os-Montes region, as well as for Portugal. In 2000, the national production of chestnuts was 33317 ton, from which 28515 ton were produced in Trás-os-Montes (INE, 2002).

The positive outcomes obtained from the chestnut are just partially known. Complementary resources associated with this culture are the macrofungi, usually collected by the local population, despite the low knowledge of their biodiversity, ecology or sustainable management. Most of the edible mushrooms associated with chestnut tree are ectomycorrhizal (ECM), establishing a "mutualistic" association in which both host and fungus obtain benefit. The plant receives inorganic nutrients and water from fungal hyphae, whereas the fungus obtains a steady supply of $\mathrm{C}$ directly from the plant (Smith and Read, 1997). In addition, the establishment of the symbiosis is required for the completion of the fungal life cycle (i.e., formation of fruiting bodies). ECM fungi have high biodiversity and species are mainly classified by structure and organisation of fruiting bodies. The estimated 5000 to 6000 species (Molina et al., 1992) belong to Basidiomycota and Ascomycota phyla.

Earlier research has shown positive effects of ECM formation on plant growth by the increased uptake and transfer of water and nutrients by the fungal hyphae (Marschner and Dell, 1994; Augé, 2001), protection of fine roots against infection with soil-bornepathogens (Marx, 1972; Cordier et al., 1998), increased host resistance to drought (Marx et al., 1970; Marx and Bryan, 1971), and heavy metals (Brunner and Frey, 2000). 
During the last years several occurrences have caused the chestnut tree area decline in Trás-os-Montes region. The occupation by other types of crops, the forthcoming of alternative food to the chestnuts for the rural population, the timber use for furniture industry and the forest fires, have been considered as determinant causes for the reduction of the area. However, environmental changes and cultivation practices (increases of tillages along the year) were probably the main reason, mostly due to the appearance of pathological diseases, as the chestnut ink disease provoked by Phythophtora sp. fungus. With the increase of phytosanitary problems, farmers are progressively changing these cultivation practices by the reduction of the number of tillages or even their elimination.

The present work intends to evaluate the effect of two different soil management practices (traditional tillage vs. non-tillage) of chestnut orchard on the macrofungi diversity and abundance. In addition, and taking into account the various components of these agroforestry systems and the ecological and physiological importance of the relation tree-fungi-soil, the present work also pretends to contribute for the general knowledge of one of the less know of these components, the macrofungi.

\section{MATERIALS AND METHODS}

\section{Site Description}

This study was conducted in two Castanea sativa Mill. orchards (one tilled and one non-tilled) with more than 100 years old, located in Oleiros, near Bragança (29T PG 80936 UTM, $915 \mathrm{~m}$ above sea level). The predominant soils are cromic dystric Cambisols (according to FAO, 1988) derived from migmatitic and gnaissic porent materials, and covering gentle to very gentle sloping surfaces (Agroconsultores \& Coba, 1991).

The prevailing climate corresponds to mean annual precipitation ranging from 1000 to $1200 \mathrm{~mm}$, and annual mean air temperatures of 10 to $14^{\circ} \mathrm{C}$, with mean maximum and minimum temperatures between $14-17^{\circ} \mathrm{C}$ and $5-7^{\circ} \mathrm{C}$, respectively (Agroconsultores \& Coba, 1991).

In each orchard five plots of $100 \mathrm{~m}^{2}$ were delimited for macrofungi harvesting. The plots were chosen with similar ecological conditions (exposition, slope and type of vegetation). In the non-tilled orchard all the plots were dominated by Genista sp. and Ulex sp. shrubs.

\section{Sampling}

From September to November 2003, all sporocarps were weekly picked from the plots. Fungi visible to the naked eye and greater than $1 \mathrm{~mm}$ in size were taken as macrofungi. The mushrooms were sorted in the laboratory by taxon, counted, dried at $30^{\circ} \mathrm{C}$ for $72 \mathrm{~h}$, and weighed. Taxonomic identification followed Moser (1983), Courtecuisse and Duhem (1995), Courtecuisse (1999), Bon (1988), Marchand (1971-86) and Bas et al. (1990-2001). Representative voucher specimens were dried and deposited at herbarium of Escola Superior Agrária of Instituto Politécnico de Bragança. During the collection period, in the chestnut orchard tilled, one tillage was made on 26 October.

Meteorological data for the study period were obtained from the weather station at the campus of Escola Superior Agrária de Bragança (data not shown), located approximately $6 \mathrm{~km}$ of the research $C$. sativa site.

\section{Data Analysis}

The number and the dry weight of the sporocarps collected during the harvesting season were reported to the hectare.

Treatment (tillage vs. non-tillage) effects were tested against mushrooms variables (number of total, mycorrhizal and non-mycorrhizal species; dry weight and number of sporocarps) by analysis of variance (ANOVA). 


\section{RESULTS AND DISCUSSION}

\section{Diversity of Macrofungi}

The diversity of macrofungi associated with $C$. sativa trees (tilled and non-tilled soils) is represented in Fig. 1. In all plots, 50 species belonging to 20 genera were identified. In the tilled orchard 17 species from 12 genera were observed, mainly from the genera Russula (3), Macrolepiota (2), Laccaria (2), and Inocybe (2). Amanita, Collybia, Cortinarius, Hebeloma, Hypholoma, Lactarius, Mycena, Tricholoma, and Xerula were represented by just one species. Non-tilled soil showed a higher number of species (47) and genera (17). Russula was the most species-rich genera, with eleven species, followed by Inocybe (9), Cortinarius (5), Tricholoma (3), and Laccaria (3). Boletus, Collybia, Lactarius, and Macrolepiota were the next species-rich genera, each containing 2 species. The genera Calocybe, Cantharellus, Hebeloma, Hypholoma, Leotia, Lycoperdon, and Xerocomus were also found but represented by only one species.

Nine genera were common in both soils. Amanita sp., Mycena sp., and Xerula sp. were only found in tilled soils and Boletus sp., Calocybe sp., Cantharellus sp., Hydnum sp., Hypholoma sp., Leotia sp., Lycoperdon sp., and Xerocomus sp. in the non-tilled orchard (Fig. 1).

\section{Number and Occurrence of Species}

The total number of species found in the non-tilled $C$. sativa orchard was significantly greater than in tilled soils (Table 1). This difference was more important for mycorrhizal species than for non-mycorrhizal. From the total species collected in nontilled orchard $83 \%$ were mycorrhizal and $17 \%$ non-mycorrhizal, whereas in tilled soils $71 \%$ were mycorrhizal and $29 \%$ non-mycorrhizal.

The two $C$. sativa orchards showed a similar occurrence in number of fungal species along the harvesting season. A maximum was recorded early November, when temperatures were mild and rains abundant. In September and at the beginning of October the number of species collected was lower probably due to the colder temperature and declining of rainfall (Fig. 2).

\section{Number and Occurrence of Sporocarps}

The number of sporocarps was significantly higher in the non-tilled orchard than in the tilled one (Table 1). In the first type of management a total number of 29820 sporocarps were collected whereas in the tilled soil only 3660 sporocarps were observed.

With regard to occurrence, it is observed that the greatest number of sporocarps occurred at the same time as the observation of a higher number of species, early November, in tilled and non-tilled C. sativa orchards (Fig. 3).

\section{Production and Occurrence of Biomass}

The sporocarp production (dry weight) was significantly greater in non-tilled than in tilled soils (Table 1). At the end of the harvesting season, $15.9 \mathrm{~kg} \mathrm{dw} / \mathrm{ha}$ was collected from the non-tilled orchard and $2.9 \mathrm{~kg} \mathrm{dw} / \mathrm{ha}$ from the tilled one.

The evolution of biomass production along time changed according to the soil management (Fig. 4). In the non-tilled orchard, the higher fungi biomass production occurred in mid October, whereas in the tilled orchard it occurred early November.

\section{CONCLUSIONS}

This study demonstrated that C. sativa orchards provide a habitat for diverse macrofungal communities. However, different management practices (tilled or non-tilled) have a crucial impact on the biodiversity as well as on abundance of macrofungal communities.

The number of species, sporocarps and biomass production increased in the nontilled C. sativa orchard and decreased considerably in tilled soil. These changes were found to be statistically significant, especially for mycorrhizal species. This aspect is very 
important for chestnut producers since the mushrooms with more commercial value belong to this trophic group, namely Boletus edulis and Cantharellus cibarius. The mycorrhizal ratio, considered by some authors to be an index of forest health (Lagana et al., 2002), indicates that both soils (tilled and non-tilled) are in good health.

Soil tillage has a considerable influence on the fungal community, especially among mycorrhizal species, which are intrinsically linked to the vegetation. So, it seems that the study of macrofungal communities probably may be included in environmental biomonitoring programs since changes in composition of fungal community reflect changes in the ecosystem to which they belong. However it will be necessary to continue this study for a longer period, for knowing further effects of management on the diversity of macrofungi.

\section{ACKNOWLEDGEMENTS}

Research supported by the Portuguese AGRO Project $\mathrm{n}^{\circ}$ 689: “Demonstração do papel dos macrofungos na vertente agronómica, económica e ambiental. Aplicação à produção de plantas de castanheiro, pinheiro e carvalho".

\section{Literature Cited}

Agroconsultores \& Coba. 1991. Carta dos solos, carta do uso actual da terra e carta da aptidão da terra do nordeste de Portugal. Projecto de desenvolvimento rural integrado de Trás-os-Montes, Universidade de Trás-os-Montes e Alto Douro.

Augé, R.M. 2001. Water relations, drought and vesicular-arbuscular mycorrhizal symbiosis. Mycorrhiza 11:3-42.

Bas, C., Kuyper, T.H.W., Noordeloos, M.E. and Vellinga, E.C. 1990-2001. Flora Agaricina Neerlandica: Critical monographs on families of agarics and boleti occuring in the Netherlands. Volume 1-5. A.A. Balkema, Rotterdam, Broakfield.

Bon, M. 1988. Guia de campo de los Hongos de Europa. Ediciones Omega, Barcelona.

Brunner, I. and Frey, B. 2000. Detection and localisation of aluminium and heavy metals in ectomycorrhizal Norway spruce seedlings. Environ. Poll. 108:121-128.

Cordier, C., Pozo, M.J., Barea, J.M., Gianinazzi, S. and Gianinazzi-Pearson, V. 1998. Cell defence responses associated with localised and systemic resistance to Phytophthora parasitica induced in tomato by an arbuscular mycorrhizal fungus. Mol. PlantMicrobe Interact. 11:1017-1028.

Courtecuisse, R. and Duhem, B. 1995. Mushrooms and Toadstools of Britain and Europe. HarperCollins Publishers, London.

Courtecuisse, R. 1999. Mushrooms of Britain and Europe. HarperCollins Publishers, London.

Instituto Nacional de Estatística, Portugal 2002. Estatísticas Regionais da Produção Vegetal a Animal 1990-2000. Lisboa, Portugal.

Lagana, A., Angiolini, C., Loppi, S., Salerni, E., Perini, C., Barluzzi, C. and De Dominicis, V. 2002. Periodicity, fluctuations and successions of macrofungi in fir forest (Abies alba Miller) in Tuscany, Italy. For. Ecol. Manag. 169:187-202.

Marchand, A. 1971-1986. Champignons du Nord et du Midi. Tome 1-9. Soc. Mycol. Pyrénées Mediterranéenes, Perpignan.

Marchner, H. and Dell, B. 1994. Nutrient uptake in mycorrhizal symbiosis. Plant Soil. 159:89-102.

Marx, D.H. and Bryan, W.C. 1971. Influence of ectomycorrhizae on survival and growth of aseptic seedlings of loblolly pine at high temperature. For. Sci. 17:37-41.

Marx, D.H. 1972. Ectomycorrhizae as biological prevention to pathogenic root infection. Ann. Ver. Phytopathol. 10:426-434.

Marx, D.H., Bryan, W.C. and Davey, C.B. 1970. Influence of temperature on aseptic synthesis of ectomycorrhizae by Thelephora terrestris and Pisolithus tinctorius on loblolly pine. For. Sci. 16:424-431.

Molina, R., Massicotte, H. and Trappe, J.M. 1992. Specificity phenomena in mycorrhizal symbiosis: community-ecological consequences and practical implications. p.357-423. 
In: M.F. Allen (ed.), Mycorrhizal Functioning, an Integrative Plant-Fungal Process, Chapman and Hall, New York.

Moser, M. 1983. Keys to Agarics and Boleti (Polyporales, Boletales, Agaricales, Russulales). Roger Phillips, London.

Smith, S.E. and Read, D.J. 1997. Mycorrhizal symbiosis. $2^{\text {nd }}$ ed., Academic Press.

\section{Tables}

Table 1. Mean number \pm SE of total, nonmycorrhizal and mycorrhizal species, total dry weight, and total number of sporocarps in $C$. sativa orchard tilled and non-tilled.

\begin{tabular}{llccc}
\hline & & Non-tilled & Tilled & $p$ \\
\hline $\mathrm{N}^{\mathrm{o}}$ of species $\left(100 \mathrm{~m}^{2}\right)$ & Total & $23.2 \pm 2.3$ & $6.0 \pm 1.1$ & $* * *$ \\
& Non-mycorrhizal & $3.6 \pm 0.6$ & $1.4 \pm 0.6$ & $*$ \\
& Mycorrhizal & $19.6 \pm 1.7$ & $4.6 \pm 0.6$ & $* * *$ \\
Dry weight $\left(\mathrm{g} / 100 \mathrm{~m}^{2}\right)$ & & $156 \pm 29.2$ & $28 \pm 4.3$ & $* *$ \\
$\mathrm{~N}^{\mathrm{o}}$ of sporocarps $\left(100 \mathrm{~m}^{2}\right)$ & & $297 \pm 61.2$ & $35 \pm 9.9$ & $* *$ \\
\hline
\end{tabular}

Statistical significance: ${ }^{*} \mathrm{p}<0.05 ;{ }^{* *} \mathrm{p}<0.01 ;{ }^{* * *} \mathrm{p}<0.001$

\section{Figures}

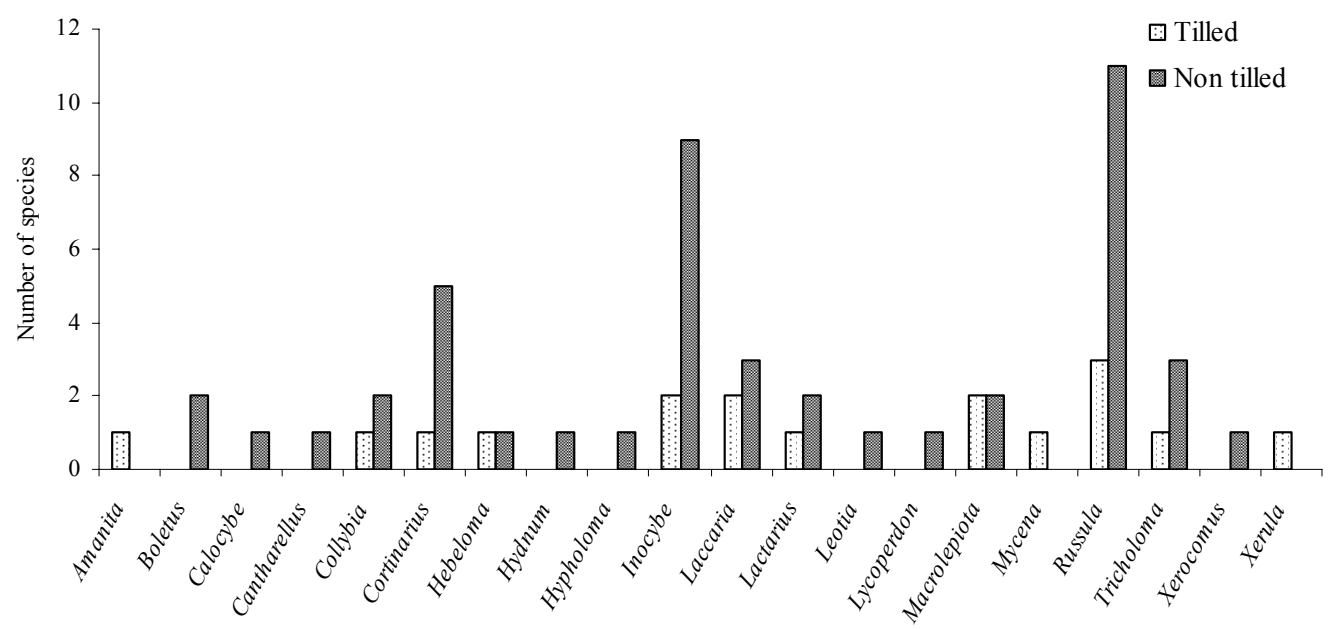

Fig. 1. Macrofungi genera distribution in C. sativa tilled and non-tilled orchards of a number of species (autumn-winter 2003). 


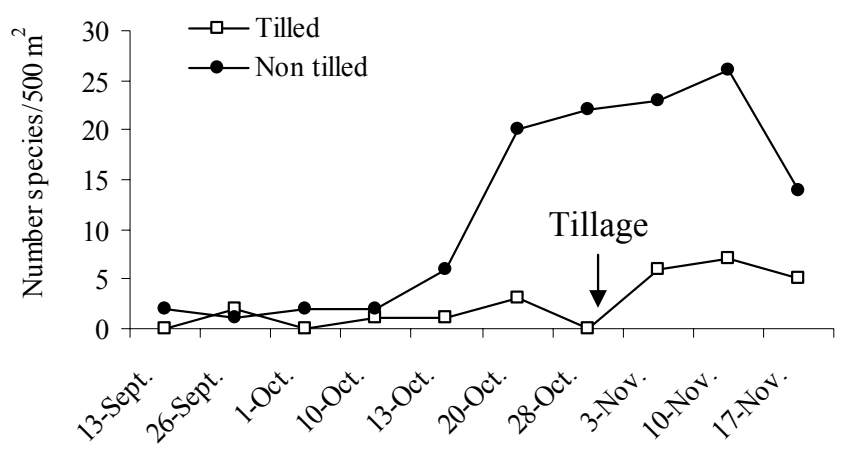

Fig. 2. Total macrofungi species number collected in $500 \mathrm{~m}^{2}$ of $C$. sativa tilled and nontilled orchards along harvesting season (autumn-winter 2003). The arrow indicates when tillage was made (26 October).

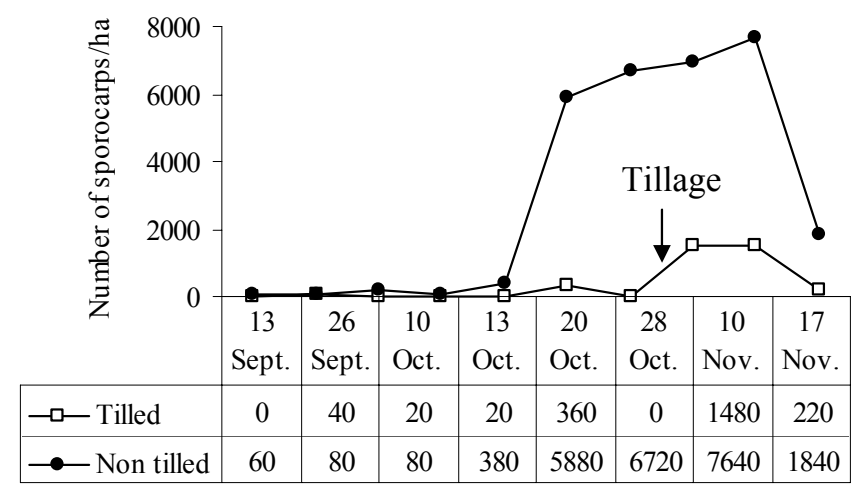

Fig. 3. Number of total sporocarps per hectare collected in C. sativa tilled and non-tilled orchards along harvesting season (autumn-winter 2003). The arrow indicates when tillage was made (26 October).

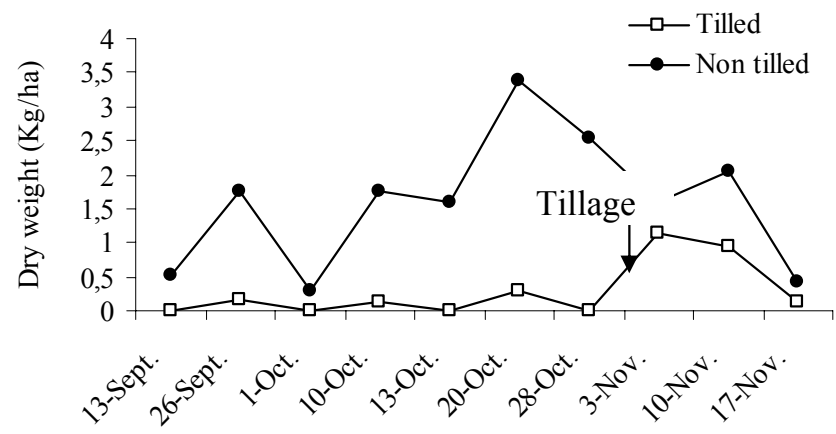

Fig. 4. Dry weight (kg/ha) of total sporocarps collected in C. sativa tilled and non-tilled orchards along harvesting season (autumn-winter 2003). The arrow indicates when tillage was made (26 October). 